Toxicology, 39 (1986) 149-163

Elsevier Scientific Publishers Ireland Ltd.

\title{
EVALUATION OF CHRONIC TOXICITY AND CARCINOGENESIS IN RODENTS WITH THE SYNTHETIC ANALGESIC, TILIDINE FUMARATE*
}

EDWARD J. McGUIRE**, CARLO J. DiFONZO, RONALD A. MARTIN and FELIX A. DE LA IGLESIA

Department of Pathology and Experimental Toxicology, Warner-Lambert/Parke-Davis Pharmaceutical Research, Ann Arbor, MI 48105, Warner-Lambert/Parke-Davis Research Institute, Mississauga, Ontario (Canada) and Department of Environmental and Industrial Health Sciences, School of Public Health, University of Michigan, Ann Arbor, MI 48109 (U.S.A.)

(Received July 2nd, 1985)

(Accepted November 4 th, 1985)

\section{SUMMARY}

The carcinogenic potential of tilidine fumarate, a synthetic analgesic, was studied for 80 and 104 weeks in mice and rats, respectively. Groups of 50 albino CF1 mice and 65 albino Wistar rats of each sex received tilidine fumarate-lactose blend $(1: 1)$ at doses of 100,40 and $16 \mathrm{mg} / \mathrm{kg}$. The control groups consisted of 100 mice and 115 rats of each sex and received the lactose vehicle only. Treatment-related non-neoplastic changes consisted of reversible, increased cytoplasmic eosinophilia of hepatocytes in high and mid dose rats corresponding to areas of proliferating smooth endoplasmic reticulum; and an increased incidence in high dose rats of proliferative or cystic lesions of the biliary epithelium. Adequate survival rates allowed stringent statistical analysis of neoplasia. Tilidine did not evoke increased tumor incidences or changes in the average latency or onset of tumors in either species. The most frequent tumors represented spontaneous neoplasia characteristic of historical background incidence in these strains. In mice, the only statistically significant $(P<0.01)$ variation in tumor incidence was an increased rate of lung alveologenic adenocarcinomas in females at $100 \mathrm{mg} / \mathrm{kg}$ $(24 \%)$, compared with the concurrent untreated controls $(10 \%)$, but without a statistically significant difference from historical control data (27\%). Female rats given $100 \mathrm{mg} / \mathrm{kg}$ showed statistically significant $(P<0.01)$ decreased

\footnotetext{
* Presented at Federation Proceedings, St. Louis, MO, 1984.

**Address all correspondence to: E.J. McGuire, Warner-Lambert/Parke-Davis Pharmaceutical Research, Ann Arbor, MI 48105, U.S.A.
} 
incidences of mammary fibroadenoma and pituitary adenoma. From these data, it was concluded that the synthetic analgesic tilidine does not possess tumorigenic potential in rodents.

Key words: Carcinogenesis; Chronic toxicity; Synthetic analgesic; Tilidine (Valoron)

\section{INTRODUCTION}

The substituted cyclohexenylamine tilidine (Valoron) was synthesized by Satzinger [1]. The pharmacology profile indicated analgesic properties [2] . Later, pharmacokinetic studies $[3,4]$, animal toxicology $[5,6]$, metabolism [7-9], initial clinical investigations [10], and the analytical profile [11] were reported. The pharmacological, epidemiological and clinical aspects of tilidine dependence and abuse have been reviewed [12]. The activity profile of tilidine remains controversial with respect to the involvement of opiate receptors $[13,14]$.

The animal experiments reported herein were undertaken to evaluate the carcinogenic potential of tilidine in rats and mice. There are minimal published data available on the long-term toxicity or carcinogenicity of substituted cyclohexenylamines with potent analgesic activity. A preliminary report was available earlier [15].

\section{MATERIALS AND METHODS}

\section{Chemical}

Tilidine (Fig. 1), a substituted cyclohexenylamine, trans-( \pm )-2-(dimethylamino)-1-phenyl-3-cyclohexene-1-carboxylic acid ethyl ester, has a molecular formula of $\mathrm{C}_{17} \mathrm{H}_{23} \mathrm{NO}_{2}$ and a molecular weight of 273.4. The fumarate salt of tilidine in a lactose blend $(1: 1)$ was used in the conduct of these studies, and throughout this paper dose levels are expressed in terms of this formulation.

Animals and housing.

Random bred, barrier raised albino $\mathrm{CF}_{1}$ mice and albino Wistar rats were supplied by Carworth Farms, New City, NY, and Hilltop Laboratory Animals,<smiles>CCCCC1(c2ccccc2)CCC=CC1N(C)C</smiles>

Fig. 1. Tilidine: trans-( \pm )-2-(dimethylamino)-1-phenyl-3-cyclohexene-1-carboxylic acid ethyl ester. 
Inc., Scottdale, PA, respectively. These animal strains were selected for these experimental studies because of historical data accumulated in this laboratory since the inception of the in-house carcinogenesis bioassay program in 1967. These strains have adequate survival rates at 80 weeks for mice and 104 weeks for rats, and historically have shown a moderate incidence of spontaneous neoplasia, and a low incidence of intercurrent pathology.

Clinically substandard animals were culled during a 2-week quarantine period and the remaining animals were assigned randomly to experimental groups to provide comparable mean body weights at study initiation. Animals assigned were approximately 42 days old at study initiation. Rats were housed individually in suspended stainless-steel cages while mice were housed in groups of 3 in plastic boxes with pressed hardwood bedding chips. Some male mice were subsequently separated into individual units as a result of aggressive behavior. The animals were maintained in clean rooms with controlled temperature $\left(23 \pm 2^{\circ} \mathrm{C}\right)$ and relative humidity $(40-60 \%)$. Each room had 18 fresh air exchanges per hour and was maintained on an 11-h photoperiod. The species were housed in separate animal rooms. Fresh water was supplied ad libitum and animals were offered standard laboratory ration (Purina Lab Chow).

\section{Experimental groups}

Dose levels selected for these experiments were based upon an overall assessment of effects in previous acute, subchronic and long-term toxicology studies. Briefly, tilidine hydrochloride was tested in rats, orally at doses of 25,50 and $100 \mathrm{mg} / \mathrm{kg}$ for 6 months [5]. Central nervous system excitation was observed in rats given $100 \mathrm{mg} / \mathrm{kg}$ orally. Histologic examination of these high dose animals revealed cloudy swelling and fatty change of centrilobular hepatocytes. These reversible liver changes were slight in rats given $50 \mathrm{mg} / \mathrm{kg}$. Based upon these data, the maximum tolerated dose was estimated to be $100 \mathrm{mg} / \mathrm{kg}$. Tilidine fumarate, at a dose of $100 \mathrm{mg} / \mathrm{kg}$ administered as a dietary admixture for 8 weeks, was well tolerated. Food consumption was slightly reduced and the only clinical sign observed was abdominal fur loss. Therefore, groups of 50 mice and 65 rats of each sex received tilidine fumarate-lactose blend $(1: 1)$ at 100,40 and $16 \mathrm{mg} / \mathrm{kg} /$ day. The untreated control groups consisted of 100 mice and 115 rats of each sex.

\section{Experimental procedures}

Animals were weighed once weekly for the initial 6 months of study and biweekly thereafter. Food consumption was measured weekly throughout the entire experimental period. Drug levels in diet were adjusted weekly to compensate for changes in mean body weight and food consumption.

All animals were observed daily for evidence of overt toxic reactions. Physical examinations were performed pretest and at monthly intervals. Ophthalmic examinations were performed on all mice at monthly intervals and in rats pretest and at 6-month intervals. Clinical laboratory studies were conducted on 5 rats/sex group sacrificed at 6,12 and 18 months, and on at 
least 10 animals/sex group sacrificed at termination (24 months). Serum analyses included fasting blood glucose (ferrocyanide oxidation), blood urea nitrogen (BUN: diacetyl monoxime reaction), alkaline phosphatase ( $p$ phenyl phosphate hydrolysis) and glutamate pyruvate transaminase (GPT: dinitrophenylhydrazine reaction). All tests were conducted by Auto-Analyzer with commercially available kits and reagents. Hematologic examinations included hemoglobin (Coulter Hemoglobinometer), hematocrit (Clay-Adams Autocrit), total red blood cells and total white blood cells (Coulter Counter). Platelets were counted manually in a Neubauer counting chamber. Analyses on urine included specific gravity (American Optical T.S. Meter), bilirubin (Ames Icotest), and occult blood, ketones, glucose, protein, and bilirubin (Ames Labstix). Five rats per sex group were withdrawn from compound administration after 88 weeks of dosing and were maintained on study to 104 weeks to evaluate the reversibility of liver changes [6].

\section{Pathology studies}

Moribund animals were sacrificed for humane reasons and to minimize onset of autolytic changes in the event of death. All animals were autopsied; those sacrificed in extremis were considered deaths for the purposes of data

analysis. For animals sacrificed at termination, organ weights and organ to body weight ratios were determined for gonads, liver, kidneys, prostate, and uterus. In rats, thyroid and adrenal weights also were determined. After gross pathologic examinations, tissues and gross abnormalities from all animals were processed and evaluated microscopically.

\section{Methods of statistical analysis}

All tumors noted during gross pathologic examination were processed for microscopic evaluation. The time of onset of all microscopically characterized tumors was set when they were first noted during clinical examination in the in vivo phase. The onset of internal, non-palpable tumors was established as the date of autopsy. The methodology for analyzing the tumor incidences followed a modified life-table technique [16]. The criteria for tumorigenic response were based on histotyping of tumors, dose relationships, statistically significant differences in tumor frequency $(P<0.01)$, changes in onset, average latency, and the occurrence of highly unusual or unexpected tumors. For non-tumor data (i.e., clinical laboratory parameters and organ weights and ratios), pair-wise comparison of each treated group to untreated controls was made by analysis of variance and the Student's $t$-test [17].

\section{RESULTS}

Survival data of animals fed the various drug regimens are shown in Figs. 2 and 3 for mice and rats, respectively. Group survival rates in both mice $(29-72 \%)$ and rats (46-58\%) ensured adequate statistical power for tumor analysis. Mice died mainly as a result of murine leukemia or, in the case of males, obstructive uropathy as a result of aggressive behavior and mutilation. 

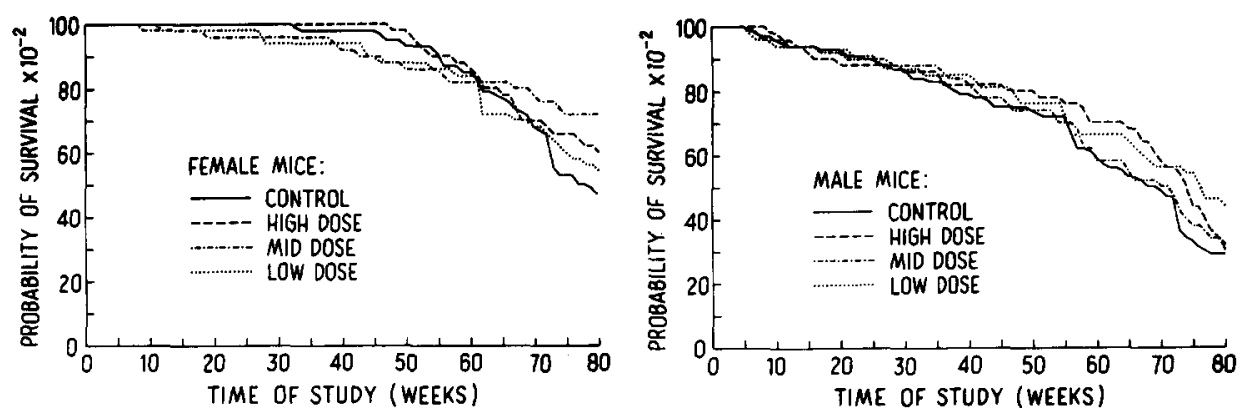

Fig. 2. Survival rate of mice fed different levels of tilidine fumarate for 80 weeks.

Upon gross examination, animals later confirmed microscopically to have murine leukemia, generally had marked enlargement of lymph nodes, thymus and spleen. The thymus and lymph nodes were soft with a homogeneous pale tan color, while the spleen was dark red, firm and occasionally focally necrotic. Surviving animals remained in satisfactory clinical condition throughout the studies. Clinical signs and ophthalmic lesions were related to aging changes in both species. There was significant dose-related body
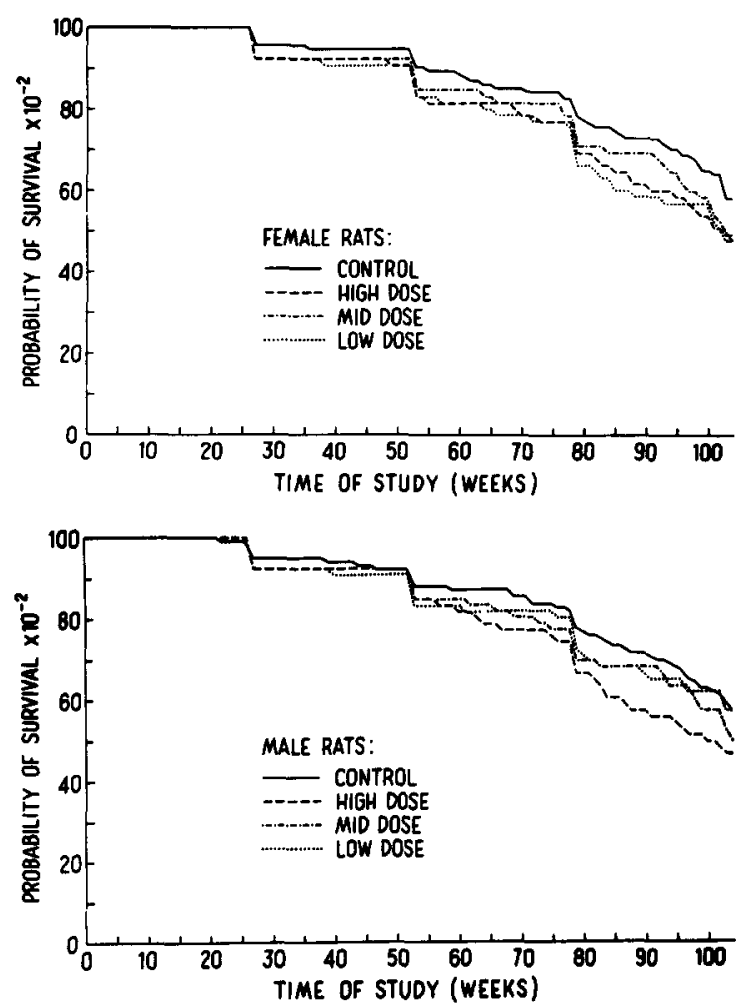

Fig. 3. Survival rate of rats fed different levels of tilidine fumarate for 104 weeks. 


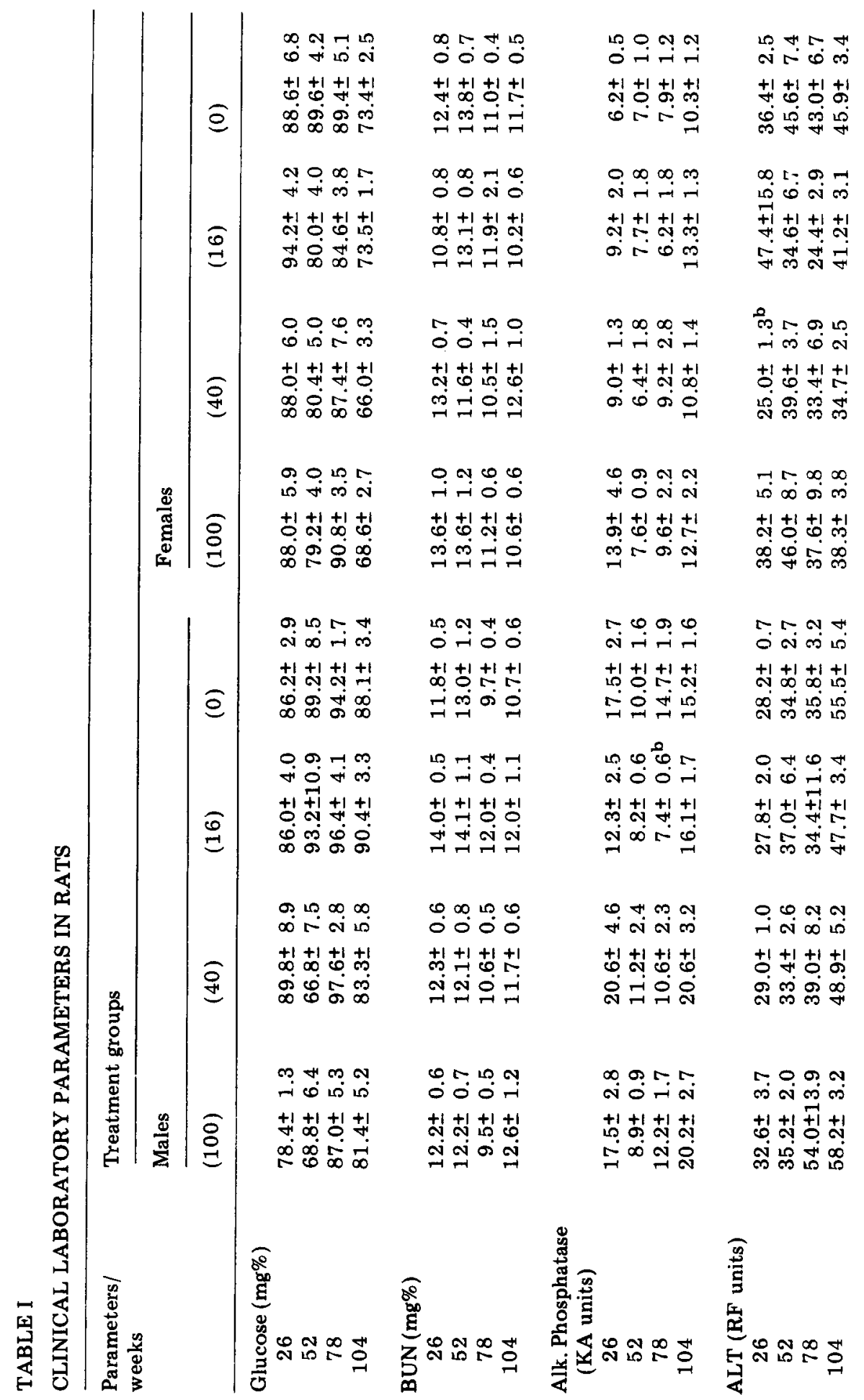




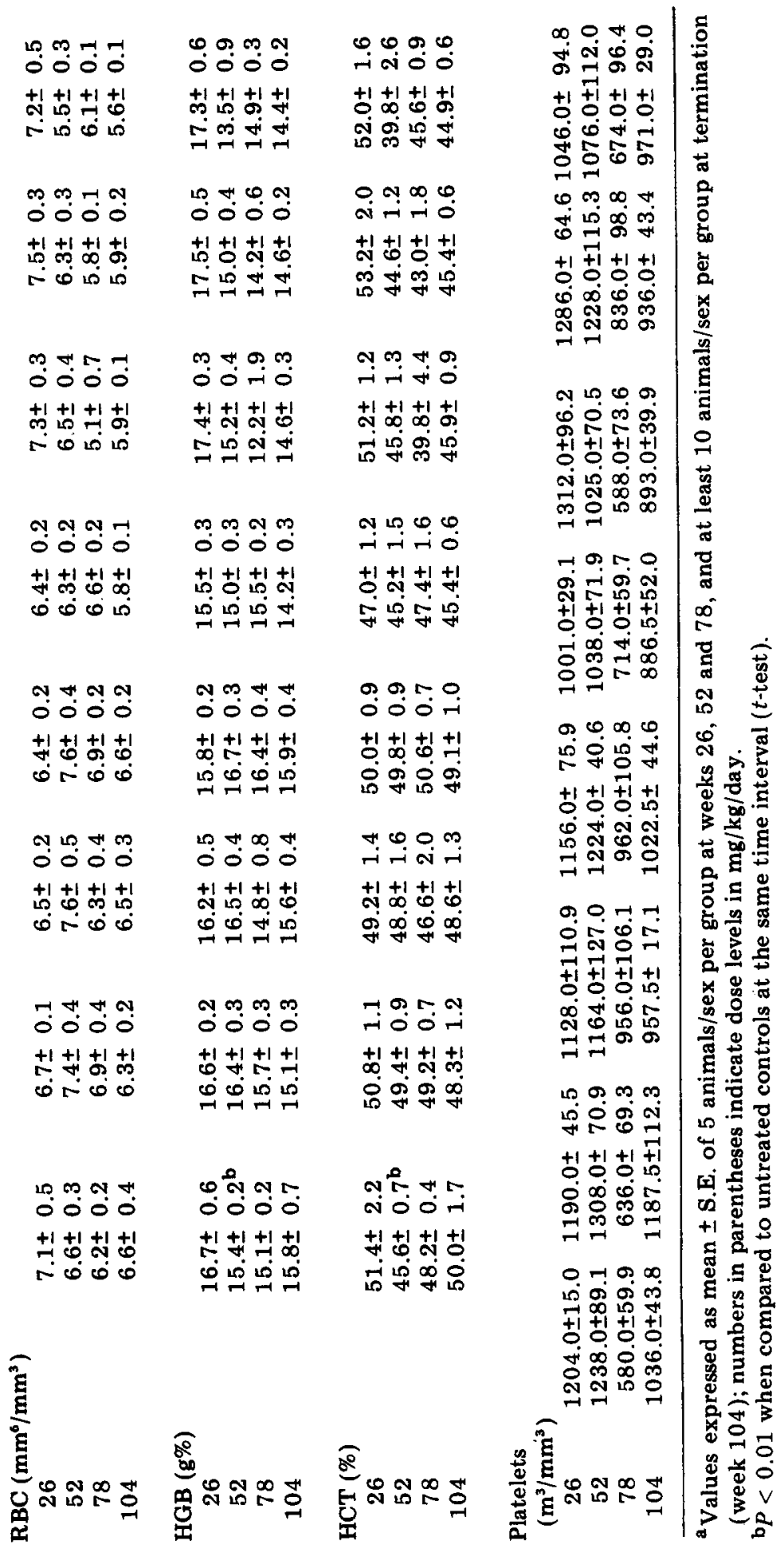


weight gain suppression during the final year of study in rats given 100 and $40 \mathrm{mg} / \mathrm{kg}$. Body weight gain suppression in males and females given doses of 100,40 and $16 \mathrm{mg} / \mathrm{kg}$ was $26 \%, 14 \%$ and $6 \%$, and $23 \%, 6 \%$ and $4 \%$, respectively. Rats removed from treatment after 88 weeks did not show significant weight gain during the withdrawal period. Only minor variations in food consumption occurred in both species. In rats, no significant differences were observed in biochemical, hematological and urinalysis parameters of treated and control groups. Selected parameters from those evaluated, and relevant to liver and kidney function, are summarized in Table I.

Dose-related increases in absolute liver weights and ratios were observed in treated male and female rats surviving to study termination (Table II). Absolute liver weights and ratios were comparable to control values in animals given drug for 88 weeks followed by 16 weeks of withdrawal. Other variations in absolute organ weights and associated ratios, in both rats and mice, were related to either body weight gain suppression or were considered incidental, and could not be correlated with histopathologic findings.

Non-neoplastic microscopic changes associated with treatment occurred only in rats. Correlation of light and electron microscopic findings indicated that increased cytoplasmic eosinophilia of hepatocytes in animals given 100 and $40 \mathrm{mg} / \mathrm{kg}$ corresponded to areas of proliferating smooth endoplasmic reticulum [6]. This histological change was dose and time related and reversible following cessation of dosing. Significantly increased incidence of bile duct proliferation and/or cholangiolar cysts was observed in rats given $100 \mathrm{mg} / \mathrm{kg}$. No histopathologic evidence of malignancy was noted either in the proliferative or cystic lesions.

The tumor types identified in treated mice were similar to those in untreated controls (Table III). No significant differences in mean times of appearance or onset were apparent (Table IV). The most frequent tumor types were bone osteomas and leukemia prevalent in females and alveologenic adenocarcinomas in both sexes. The only statistically significant variation $(P<0.01)$ in tumor incidence was increased lung alveologenic adenocarcinomas in females given $100 \mathrm{mg} / \mathrm{kg}(24 \%)$, in comparison with controls (10\%). However, the incidence of this commonly occurring tumor type was less than that noted in historical controls $(41 / 150 ; 27 \%)$.

The tumor types in treated rats also were similar to those in controls. The most common neoplasms in both sexes were hepatocellular adenomas, pituitary adenomas, thyroid parafollicular cell tumors, and leukemia; and additionally, mammary adenocarcinomas or fibroadenomas, and uterine polyps were found in females (Table III). No significant differences in mean time of appearance of tumors were observed (Table IV). The incidence of hepatocellular adenomas was increased in females given 100 and $40 \mathrm{mg} / \mathrm{kg}$, but no statistically significant difference was evident. High dose females showed a significant decrease $(P<0.01)$ in the incidence of both mammary fibroadenomas and pituitary adenomas. 


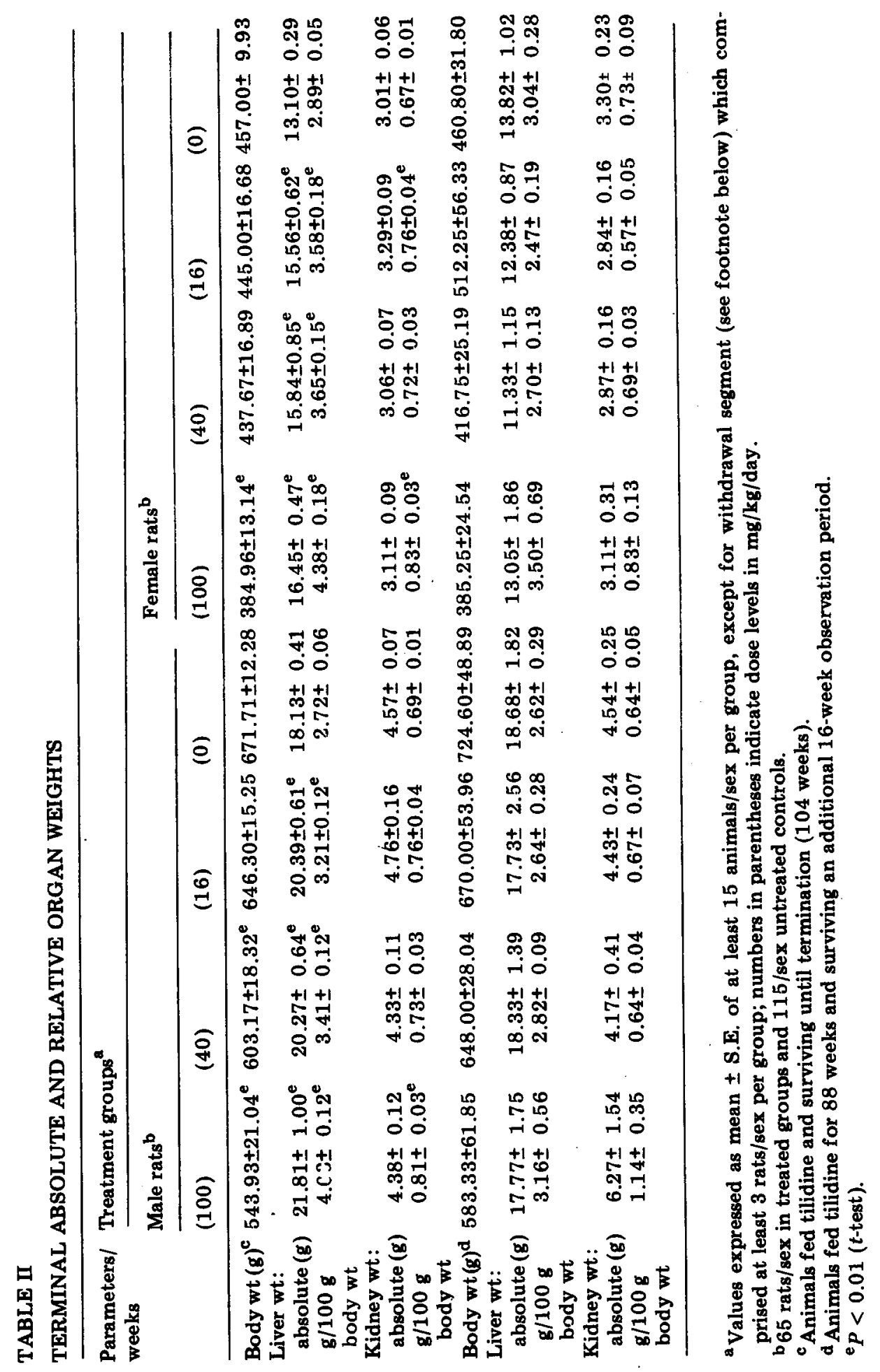




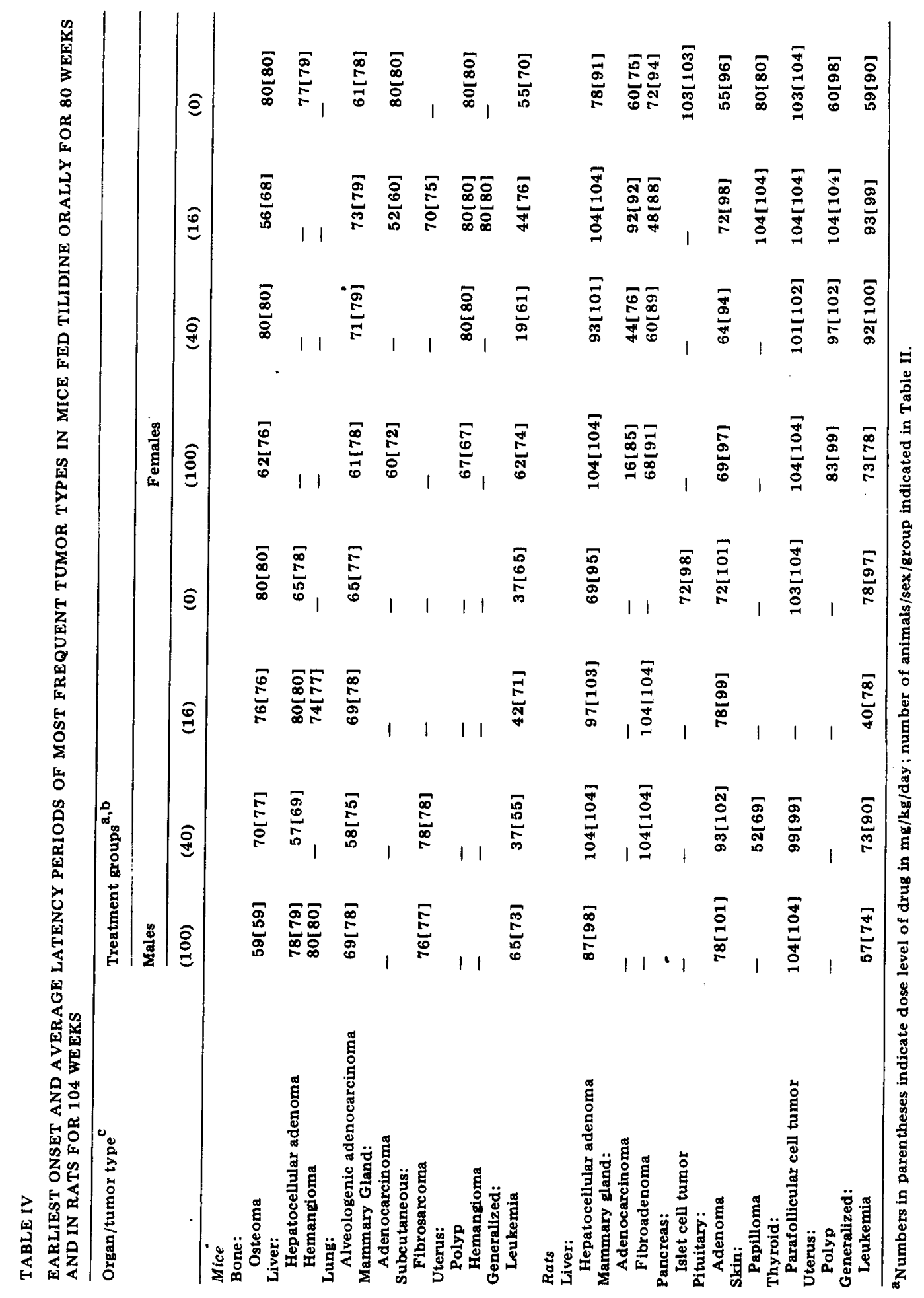


TABLE III

DISTRIBUTION OF MOST FREQUENT TUMOR TYPES IN MICE GIVEN TILIDINE ORALLY FOR 80 WEEKS AND IN RATS FOR 104 WEEKS

\begin{tabular}{|c|c|c|c|c|c|c|c|c|}
\hline \multirow[t]{3}{*}{ Organ/tumor type $e^{b, c}$} & \multicolumn{8}{|c|}{ Treatment groups ${ }^{\mathrm{a}}$} \\
\hline & \multicolumn{4}{|l|}{ Males } & \multicolumn{4}{|c|}{ Females } \\
\hline & $(100)$ & $(40)$ & (16) & $(0)$ & $(100)$ & $(40)$ & (16) & (0) \\
\hline \multicolumn{9}{|l|}{$\begin{array}{l}\text { Mice } \\
\text { Bone: }\end{array}$} \\
\hline $\begin{array}{l}\text { Usteoma } \\
\text { Liver: }\end{array}$ & 1 & 0 & 1 & 1 & $\gamma$ & 0 & 2 & 0 \\
\hline $\begin{array}{l}\text { Hepatocellular adenoma } \\
\text { Hemangioma }\end{array}$ & $\begin{array}{l}2 \\
1\end{array}$ & 4 & $\begin{array}{l}3 \\
2\end{array}$ & $\begin{array}{l}9 \\
0\end{array}$ & $\begin{array}{l}0 \\
0\end{array}$ & $\begin{array}{l}0 \\
0\end{array}$ & $\begin{array}{l}0 \\
0\end{array}$ & 2 \\
\hline Lung: & & & & & & & & \\
\hline Alveologenic adenocarcinoma & 9 & 9 & 7 & 15 & $12^{c}$ & 11 & 7 & 10 \\
\hline $\begin{array}{l}\text { Mammary gland: } \\
\text { adenocarcinoma }\end{array}$ & 0 & 0 & 0 & 0 & 4 & 0 & 2 & 1 \\
\hline $\begin{array}{l}\text { Subcutaneous: } \\
\text { Fibrosarcoma }\end{array}$ & 1 & $\cdot 1$ & 0 & 0 & $\mathbf{0}$ & 0 & 2 & $\mathbf{0}$ \\
\hline Uterus: & & & & & & & & \\
\hline Polyp & - & - & - & - & 1 & 3 & 2 & 3 \\
\hline Hemangioma & - & - & - & - & $\mathbf{0}$ & 0 & 2 & $\mathbf{0}$ \\
\hline $\begin{array}{l}\text { Generalized: } \\
\text { Leukemia }\end{array}$ & 4 & 5 & 4 & 5 & 3 & 9 & 11 & 18 \\
\hline $\begin{array}{l}\text { Animals with benign tumors }{ }^{d, e} \\
\text { Animals with malignant tumors } \\
\text { Animals with tumors }\end{array}$ & $\begin{array}{r}4 \\
14 \\
17\end{array}$ & $\begin{array}{r}6 \\
18 \\
22\end{array}$ & $\begin{array}{r}5 \\
16 \\
17\end{array}$ & $\begin{array}{r}9 \\
21 \\
25\end{array}$ & $\begin{array}{r}8 \\
18 \\
21\end{array}$ & $\begin{array}{r}7 \\
19 \\
25\end{array}$ & $\begin{array}{r}6 \\
21 \\
24\end{array}$ & $\begin{array}{l}14 \\
32 \\
38\end{array}$ \\
\hline $\begin{array}{l}\text { Rats } \\
\text { Liver : }\end{array}$ & & & $\cdot$ & & & & & \\
\hline $\begin{array}{l}\text { Hepatocellular adenoma } \\
\text { Mammary gland: }\end{array}$ & 3 & 3 & 6 & 4 & 7 & 5 & 1 & 2 \\
\hline Adenocarcinoma & 0 & 0 & 0 & 0 & 6 & 7 & 1 & 2 \\
\hline Fibroadenoma & 0 & 1 & 1 & 0 & $6^{\mathrm{c}}$ & 11 & 25 & 29 \\
\hline $\begin{array}{l}\text { Pancreas: } \\
\text { Islet cell tumor }\end{array}$ & 0 & 0 & 0 & 5 & 0 & 0 & $\mathbf{0}$ & 1 \\
\hline Pituitary: & & & & & & & & \\
\hline $\begin{array}{l}\text { Adenoma } \\
\text { Skin: }\end{array}$ & 7 & 9 & 9 & 21 & $8^{\mathrm{c}}$ & 18 & 15 & 46 \\
\hline Papilloma & 0 & 3 & 0 & 0 & 0 & 0 & 1 & 1 \\
\hline $\begin{array}{l}\text { Thyroid: } \\
\text { Parafollicular cell tumor }\end{array}$ & 2 & 1 & 0 & 7 & 1 & 2 & 1 & 7 \\
\hline $\begin{array}{l}\text { Uterus: } \\
\text { Polyp }\end{array}$ & - & - & - & - & 4 & 3 & 4 & 11 \\
\hline $\begin{array}{l}\text { Generalized: } \\
\text { Leukemia }\end{array}$ & 6 & 7 & 7 & 6 & 2 & 5 & 2 & 3 \\
\hline $\begin{array}{l}\text { Animals with benign tumors }{ }^{d, e} \\
\text { Animals with malignant tumors }\end{array}$ & $\begin{array}{l}29 \\
12\end{array}$ & $\begin{array}{l}20 \\
14\end{array}$ & $\begin{array}{r}22 \\
9\end{array}$ & $\begin{array}{l}45 \\
16\end{array}$ & $\begin{array}{l}34 \\
13\end{array}$ & $\begin{array}{l}32 \\
12\end{array}$ & $\begin{array}{r}36 \\
8\end{array}$ & $\begin{array}{l}74 \\
17\end{array}$ \\
\hline Animals with tumors & 38 & 29 & 29 & 55 & 40 & 36 & 39 & 81 \\
\hline
\end{tabular}

\footnotetext{
${ }^{a}$ Numbers in parentheses indicate dose levels of drug in $\mathrm{mg} / \mathrm{kg} / \mathrm{day}$; number of animals/. sex/group indicated in Table II.

${ }^{b}$ Only those tumor types with a frequency of greater than $4 \%$ are listed, although all tumors are included in the overall incidence values.

${ }^{c}$ Probability analysis by life-table technique; $P<0.01$.

dSome animals may have more than one tumor.

${ }^{e}$ Chi-square test used for overall tumor incidence with a frequency of $>0.20$; exact probability test used with incidence $<0.20$.
} 


\section{DISCUSSION}

Tilidine fumarate (Valoron) ${ }^{\circledR}$, a cyclohexenyldimethylamine derivative, is an orally administered potent analgesic, with a mode of pain relief through opiate mediated effects [14,18-21]. Although extensive literature exists on the many aspects of biochemical, pharmacologic and behavioraltering actions of potent analgesics, there is a paucity of data concerning carcinogenic potential or long-term effects, even though these drugs have been widely used for many years. The principal target organ of toxicity with the salicylate analgesics is the liver. In rodents, liver damage is common following the administration of narcotic analgesics. Hepatic enlargement and fatty change were observed in rats following chronic administration of dextro-propoxyphene [22]. Liver lipids were not significantly changed after acute or chronic morphine exposure [23], although subcutaneous implantation of morphine pellets resulted in lipid accumulation in mouse hepatocytes and increased serum transaminase levels [24]. Subcutaneous or intraventricular injection of morphine sulfate also elevated transaminase levels [25]. Impaired liver function, as measured by clearance of sulfobromophthalein, was observed following subcutaneous administration of methadone [26]. Liver fatty change and increased serum transaminase levels were found in mice following single or multiple intraperitoneal injections of morphine, dihydromorphine or methadone [27]. Liver damage as exemplified by elevated serum transaminases, abnormal flocculation and turbidity tests, and morphologic variations, has been observed in patients addicted to heroin or maintained on methadone [28-32]. Hepatotoxicity in humans has been associated with propoxyphene [33-35]. These studies raise the question of whether or not opiates have direct hepatotoxic effects. Recent investigations suggested that narcotic analgesics are inherently hepatotoxic because of hepatic glutathione reduction [36,37].

Analysis of morphological and biochemical characteristics of the rat liver response to the administration of tilidine has been reported [6]. Correlation of light and electron microscopic findings showed that the glassy cytoplasmic appearance of hepatocytes corresponded to areas of enlarged cytoplasm containing proliferated smooth endoplasmic reticulum (SER). Evidence of SER membrane proliferation together with elevated microsomal enzyme activity, and increased phospholipid and protein synthesis, indicated major enzyme induction. Accompanying these cytoplasmic changes was some degree of fatty change. The withdrawal segment of these studies showed that the proliferating and stimulating action of tilidine was reversible. There were no deletereous effects on hepatic subcellular structure or function in animals sacrificed following withdrawal from drug.

Data reported herein from rodent carcinogenesis bioassays with the narcotic analgesic tilidine provide further information concerning this class of compounds. Biochemical, hematological and urinalysis parameters indicative of liver and kidney function were not altered in animals given tilidine chronically. Following the final evaluation of the tumor response, the neoplastic lesions 
included tumors commonly observed in both sexes of mice, such as osteomas, generalized lymphoid tumors, and alveologenic tumors. Rats showed more mammary gland and pituitary tumors than mice. Increased susceptibility to tumor development was not demonstrated following 80 and 104 weeks of tilidine administration in mice and rats, respectively. The analysis of tumor data indicated: (a) lack of dose-relationship for overall tumor incidences; (b) lack of dose-related increases in single tumor-type incidences; (c) lack of changes in onset and latency; and (d) absence of unusual or unexpected tumors. From these data, it was concluded that the synthetic analgesic tilidine does not possess tumorigenic potential in rodents.

\section{ACKNOWLEDGEMENTS}

Dr. Doris Jaffé, deceased, and Dr. Douglas Harding participated in the pathologic examination of these studies. Dr. L. Mitchell contributed to the conduct of the investigations. These experiments were carried out within established guidelines from the Canadian Council of Animal Care.

\section{REFERENCES}

1 G. Satzinger, Cyclohexenes I. Synthesis and reactions of 3-amino-4-phenylcyclohexenes, a novel class of analgesics. Justus Liebigs Ann. Chem., 728 (1969) 64.

2 M. Herrmann, W. Steinbrecher and W. Heldt, Pharmacology of new potent analgesic drug. Arzneim.-Forsch., 20 (1970) 977.

3 K.O. Vollmer and A. Poisson, Pharmacokinetics of DL-ethyl trans-2-dimethylamino-1phenyl-3-cyclohexene-trans-1-carboxylate hydrochloride, a new potent analgesic, in humans. 1. Blood levels and excretion in urine and feces after single oral administration of the ${ }^{14} \mathrm{C}$ labeled compound. Arzneim.-Forsch., 20 (1970) 992.

4 B. Dubinsky, M.C. Crew, M.D. Melgar, J.K. Karpowicz and F.J. DiCarlo, Correlation of analgesia with levels of tilidine and biologically active metabolite in rat plasma and brain. Biochem. Pharmacol., 24 (1975) 277.

5 M. Herrmann, J. Wiegleb and F. Leuschner, Toxicological studies on a new potent analgesic drug. Arzneim.-Forsch., 20 (1970) 983.

6 F.A. de la Iglesia, E.J. McGuire, G. Feuer and E. Schwartz, The action of tilidine fumarate on drug-metabolizing enzymes and ultrastructure of rat liver, Proc. Eur. Soc. Toxicol. (Int. Congr. Ser. No 376), 17 (1976) 220.

7 K.O. Vollmer and H. Achenbach, Metabolism of ethyl DL-trans-2-(dimethylamino)-1phenyl-3-cyclohexene-trans-1-carboxylate hydrochloride. 1. Mass spectroscopic structure elucidation of metabolites I and II and their determination in various biological fluids. Arzneim.-Forsch., 24 (1974) 1237.

8 K.O. Vollmer and A. Poisson, Metabolism of DL-trans-2-(dimethylamino)-1-phenyl-3cyclohexene-1-carboxylate hydrochloride (tilidine hydrochloride). Part 2. Studies with radioactive-labeled substance on rats and dogs. Arzneim.-Forsch., 26 (1976) 1827.

9 K.O. Vollmer and A. Von Hodenberg, Metabolism of DL-trans-2-(dimethylamino)-1phenyl-3-cyclohexene-1-carboxylate hydrochloride (tilidine hydrochloride). Part 3. Renal metabolite elimination in rats, dog and man. Arzneim.-Forsch., 27 (1977) 1706.

10 H. Teicher and H.G. Stelzer, Clinical study of valoran. Med. Welt, 34 (1970) 1456 .

11 G. Satzinger, W. Herrmann and F. Zimmermann, Analytical profile of tilidine. Pharm. Ind., $40(1978) 657$. 
12 A. Trojan and H.W. Beil, Tilidine abuse and dependence. Drug Alcohol Depend., 3 (1978) 383.

13 E. Malizia, Naloxone in toxicological recovery. Riv. Tossicol. Sper. Clin., 10 (1980) 107.

14 R.M. Bryant, J.E. Olley and M.B. Tyers, Involvement of the median raphe nucleus in antinociception induced by morphine, buprenorphine and tilidine in the rat. $\mathrm{Br}$. J. Pharmacol., 77 (1982) 615.

15 E.J. McGuire, F.A. de la Iglesia, C.J. DiFonzo, R.A Martin and J.E. Fitzgerald, Carcinogenesis studies with tilidine, a potent synthetic analgesic. Fed. Proc., 43 (1984) 365 .

16 G.R. McKinney, J.H. Weikel Jr., W.K. Webb and R.G. Dick, Use of the life-table technique to estimate effects of certain steroids on probability of tumor formation in a long-term study in rats. Toxicol. Appl. Pharmacol., 12 (1968) 68.

17 G.W. Snedecor and W.G. Cochran, Statistical Methods, 6th edn., Iowa State University Press, Ames, Iowa, 1967, p. 91.

18 D.R. Jasinski and J.G. Nutt, Progress report on the clinical assessment program of the addiction research center. Reported to the "Committee on Problems of Drug Dependence" (1973) 108.

19 D.R. Jasinski, J.D. Griffith, C.B. Carter, C.W. Gorodetsky and M.P. Kullberg, Progress report from the clinical pharmacology section of the addiction research center. Reported to the "Committee on Problems of Drug Dependence" (1974) 88.

20 G. Satzinger, Chemistry of potent analgesics: present and future. Therapiewoche, 26 (1976) 2623.

21 B. Bromm and K. Seide, The influence of tilidine and prazepam on withdrawal reflex, skin resistance reaction and pain rating in man. Pain, 12 (1982) 247.

22 J.L. Emmerson, W.R. Gibson, P.N. Harris, G.C. Todd, E.C. Pierce and R.C. Anderson, Short-term toxicity of propoxyphene salts in rats and dogs. Toxicol. Appl. Pharmacol., 19 (1971) 452.

23 R. Sablé-Anıplis, R. Agid and D. Abadie, Some effects of morphine on lipid metabolism in normal, tolerant, and abstinent rats. Life Sci., 16 (1975) 1477.

24 A. Thureson-Klein, J. Wang-Yang and I.K. Ho, Lipid accumulation in mouse hepatocytes after morphine exposure. Experientia, 34 (1978) 773.

25 Y.H. Chang and I.K. Ho, Effects of acute and continuous morphine administration on serum glutamate oxalacetate transaminase and glutamate pyruvate transaminase activities in the mouse. Biochem. Pharmacol., 28 (1979) 1373.

26 A. Hurwitz, Narcotic effects on anionic dye disposition in mice. Gastroenterology, 76 (1979) 1285.

27 W.P. Needham, L. Shuster, G.C. Kanel and M.L. Thompson, Liver damage from narcotics in mice. Toxicol. Appl. Pharmacol., 58 (1981) 157.

28 J.D. Sapira, The narcotic addict as a medical patient. Am. J. Med., 45 (1968) 555.

29 .C.E. Cherubin, S. Kane, D.R. Weinberger, E. Wolfe and T. McGinn, Persistence of transaminase abnormalities in former drug addicts. Ann. Intern. Med., 76 (1972) 385.

30 M.J. Kreek, L. Dodes, S. Kane, J. Knobler and R. Martin, Long-term methadone maintenance therapy: effects on liver function. Ann. Intern. Med., 77 (1972) 598.

31 P. Cushman Jr. and M.H. Grieco, Hyperimmunoglobulinemia associated with narcotic addiction: effects of methadone maintenance treatment. Am. J. Med., 54 (1973) 320.

32 A.G. Ostor, The medical complications of narcotic addiction. 3. Med. J. Aust., 1 (1977) 497

33 G. Bessard, J.P. Gout and M. Mingat, Hepatotoxicity of dextro-propoxyphene; a case of recurrent jaundice. Nouv. Presse. Med., 7 (1978) 4230.

34 G.K. Daikos and J.C. Kosmidis, Propoxyphene jaundice. JAMA, 232 (1975) 835.

35 A.J. Kerst and H.P. Strik, Benign recurrent cholestasis following uses of propoxyphene (Depronal). Ned. Tjoschr. Geneeskd., 123 (1979) 1570. 
36 R.C. James, D.R. Goodman and R.D. Harbison, Hepatic glutathione and hepatotoxicity: changes induced by selected narcotics. J. Pharmacol. Exp. Ther., 221 (1982) 708.

37 R.C. James and R.D. Harbison, Hepatic glutathione and hepatotoxicity. Effects of cytochrome $P$ 450-complexing compounds SKF 525-A, L-a acetylmethadol (LAAM), Nor-LAAM, and Piperonyl Butoxide. Biochem. Pharmacol., 31 (1982) 1829. 